\title{
Fractional Distillation \& Characterization of Tire Derived Pyrolysis Oil
}

\author{
Makhan Mia*, Ariful Islam*, Robiul Islam Rubel**», Mohammad Rofiqul Islam* \\ * Department of Mechanical Engineering, Rajshahi University of Engineering \& Technology, Rajshahi-6204, Bangladesh \\ ** Department of Mechanical Engineering, Bangladesh Army University of Science \& Technology, Saidpur Cantonment- \\ 5311, Bangladesh
}

(almamunme10ruet@gmail.com, arif.ruet92@gmail.com, rubel.ruet10@gmail.com, mrislam1985@yahoo.com)

\author{
*Corresponding Author; Robiul Islam Rubel, Saidpur Cantonment-5311, Bangladesh, Tel: +088-1749-399-082, \\ rubel.ruet10@gmail.com
}

Received: 03.01.2017 Accepted: 28.02.2017

\begin{abstract}
Energy is extracted recently from the waste products. Environmental pollutions are being minimized along with the addition of considerable amount of energy beside the conventional sources. The energy extracted from the waste leads a hope of alternative fuel for internal combustion engines as well as to meet other requirement. Common energy conversion method uses tire, wood, rubber to derived energy through pyrolysis. About $9.25 \%$ gaseous, $43 \%$ liquid, and $47 \%$ solid product are obtained from tire pyrolysis process at around $450^{\circ} \mathrm{C}$ temperature. The liquid fuel is directly used in the engines and that phase is a mixture of complex hydrocarbon. In this work Fractional Distillation, oxidative desulfurization and de-colorization for upgrading liquid product has been conducted. In fractional distillation 30\%, 20\%, 6.35\%, 6\%, 4.5\%, and 1.3\% by volume oils are obtained at over the temperature ranges- $121-180^{\circ} \mathrm{C}, 211-260^{\circ} \mathrm{C}, 71-120^{\circ} \mathrm{C}, 191-210^{\circ} \mathrm{C}, 181-190^{\circ} \mathrm{C}$, and $40-70^{\circ} \mathrm{C}$. Then by desulfurization around 54-58\% sulphur was removed. For desulfurization hydrogen peroxide and formic acid (2:1 ratio) are used at constant temperature and magnetic stirring rate. The obtained fraction was characterized by elemental analyses, FT-IR techniques and compared with conventional diesel fuel. Sludge oil parts may be used as furnace oil which has higher calorific value than that of other conventional furnace oils. The rest of $40-70^{\circ} \mathrm{C}$ and $71-120^{\circ} \mathrm{C}$ oil parts may be used as alternative fuel like kerosene. Thus, the aim of the present study is to investigate the suitability of pyrolysis oil as an alternative fuel for IC engine.
\end{abstract}

Keywords Pyrolysis, Fractional distillation, Tire pyrolysis oil, Upgrading and characterization.

\section{Introduction}

The energy crisis and environmental degradation are the main problems in the present days due to growing population and rapid industrialization. Around the world, there are initiatives to replace gasoline and diesel fuel due to the impact of fossil fuel crisis and hike in oil price. Millions of dollars are being invested in the search for alternative fuels. The scrap tire is one of the common and important solid wastes all over the world including developing and semi developing country. Scrap tire production shows increasing trend due to increasing number of vehicle in both developed and underdeveloped countries [1]. Nearly one billion of waste vehicle tires are accumulated each year [2]. On the other hand, the disposal of waste tires from automotive vehicles appears complex. Degrading of scrap tires in the nature is difficult for many years. There are studies and available literature on pyrolysis of waste vehicles tires. Scrap tire disposing methods like landfill, reusing and burning can create serious hazards, especially in terms of human and environmental health. Thus, waste tire is required to keep under control without damaging the environment. One of the most favorable and effective disposing method is pyrolysis, which is environmental friendly and efficient way. Therefore, these valuable carbon compounds should be utilized by converting new and clean energies. Pyrolysis is the thermal fragmentation of solid substances in an airless environment. The products obtained with this process can be easily handled, stored and easy to transportation which increases the applicability of this method. Pyrolysis fluid can be used directly as fuel in boilers and can be used in internal combustion engines after modifications such as sulphur reduction and blending with diesel fuel. It is reported that pyrolysis oil of automobile tires contains $85.54 \%$ C, $11.28 \%$ 
$\mathrm{H}_{2}, 1.92 \% \mathrm{O}_{2}, 0.84 \% \mathrm{~S}$, and $0.42 \% \mathrm{~N}_{2}$ components [3]. Pyrolysis produces three principal products, such as pyrolytic oil, gas and char. The quality and quantity of these products depend upon the reactor temperature and design. In the pyrolysis process, larger hydrocarbon chains break down at certain temperatures in the absence of oxygen that gives end products usually containing solids, liquids and gases.

Many studies have been done using systems such as thermo-gravimetric analysis, fixed bed reactor, fluidized bed pyrolysis unit, vacuum pyrolysis reactor and jet bed reactor, among which vacuum pyrolysis reactor is easier and effective. In addition, chemical products such as benzene, toluene, xylene and limonene can be obtained from waste vehicle tire pyrolysis liquid products [4-7]. The use of tire pyrolysis oil as a substitute of diesel fuel is an opportunity in minimizing the utilization of the natural resources. Isabel de Marco Rotriguez et al. [8] studied the behaviour and chemical analysis of tire pyrolysis oil. In their work it is reported that tire oil is a complex mixture of organic compounds of $5-20 \%$ carbons and with a higher proportion of aromatics. The percentage of aromatics, aliphatic, nitrogenized compounds, benzothiazol are also determined in the tire pyrolysis oil at various operating temperatures of the pyrolysis process [9]. Aromatics are found to be about $34.7 \%$ to $75.6 \%$ when the operating temperature is varied between $300^{\circ} \mathrm{C}$ and $700^{\circ} \mathrm{C}$, while aliphatic are about $19.8 \%$ to $59.2 \%$. In the same work, an automatic distillation test is carried out at $500{ }^{\circ} \mathrm{C}$ to analyze the potential use of tire pyrolysis oil as petroleum fuels. It is observed that more than $30 \%$ of the tire pyrolysis oil is easily distillable fraction with boiling points between $70^{\circ} \mathrm{C}$ and $210^{\circ} \mathrm{C}$, which is the boiling point range specified for commercial petrol. On the other hand, $75 \%$ of the pyrolytic oil has a boiling point under $370^{\circ} \mathrm{C}$, which is the upper limit specified for $95 \%$ of distilled product of diesel oil. It was mentioned that distillation carried out between $150^{\circ} \mathrm{C}$ and $370^{\circ} \mathrm{C}$ has a higher proportion of the lighter and heavier products and a lower proportion of the middle range of products than commercial diesel oil structure. The influences of the distillation process on raw pyrolytic fuel properties and on engine performance are studied in a DI diesel engine by using different test fuels which actually a blends of different pyrolytic tire oil and diesel fuel.

The distillation process improved the fuel properties of raw pyrolytic tire fuel, and the engine test results. The viscosity and sulphur content of crude TPO are the two parameters that influence the engine performance and emissions. The high viscosity of the fuel will lead to problems in the long run which include carbon deposit, oil ring sticking etc. The high viscosity is due to its large molecular mass and chemical showed that engine performance and emissions can be improved by the distillation process. The previous experimental works by the authors [10-11] studied the effect of lower and higher concentrations of the tire pyrolysis oil/diesel fuel blends on the performance, emission and combustion characteristics of a single cylinder, 4-stroke and water cooled, DI diesel engine running. They reported that $\mathrm{HC}, \mathrm{NOX}, \mathrm{CO}$ and smoke emissions usually increased with the increasing tire derived fuel content in the diesel fuel blends. Furthermore, they found that the increasing tire derived fuel content in the diesel fuel blends increased the maximum combustion pressure, rate of pressure rise and ignition delay. To investigate a new source of petrol, kerosene and diesel like fuel, study about the chemical and physical property of TPO (Tire Pyrolytic Oil) is done. In this work a simplified fractionation distillation column is used to drive oil from waste tire. Again desulfurize, decolorize of pyrolysis oil is done to prepare eco-friendly energy source compare to the conventional diesel fuel.

\section{Working Plant}

A previously set pyrolysis plant shown in Fig. 1 is used to collect the oil following the process chart in Fig. 2. Major parts of the pyrolysis plant are:- (a) Reactor, (b) Fractionating column, (c) 1 st condenser, (d) CTPOReservoir, (e) 2nd condenser, and (f) HQO-Reservoir.

\subsection{Temperature distribution of tire pyrolysis plant}

The temperature distribution is very important factor for pyrolysis plant. Initially reactor temperature is $18^{\circ} \mathrm{C}$. Then after every 30 minutes, temperature reading is recorded during heating of the reactor. The reactor is heated at an increasing rate up to first 120 minutes of running operation. Then the next 120 minutes was maintained at constant temperature near about $455^{\circ} \mathrm{C}\left( \pm 5^{\circ} \mathrm{C}\right)$. Then the portable parts of the insulated side wall of reactor shield are removed for cooling. Temperature distribution during the reactor heating operation is presented in Fig. 3.

\subsection{Performance of the plant}

The performance data is collected during operating time of pyrolysis plant presented in Table 1. The reactor temperature becomes stagnant at $455^{\circ} \mathrm{C}$. The condenser outlet is fixed at $20 \mathrm{Lit} / \mathrm{min}$.

\subsection{Pyrolysis products from pilot plant}

In tire pyrolysis system liquid, char and gases products are obtained. Pyrolytic liquid is the main products in pyrolysis process. Char and gases are two by products which may be used as fuel for reactor heating purpose. Several runs are carried out by using prepared tire waste samples.

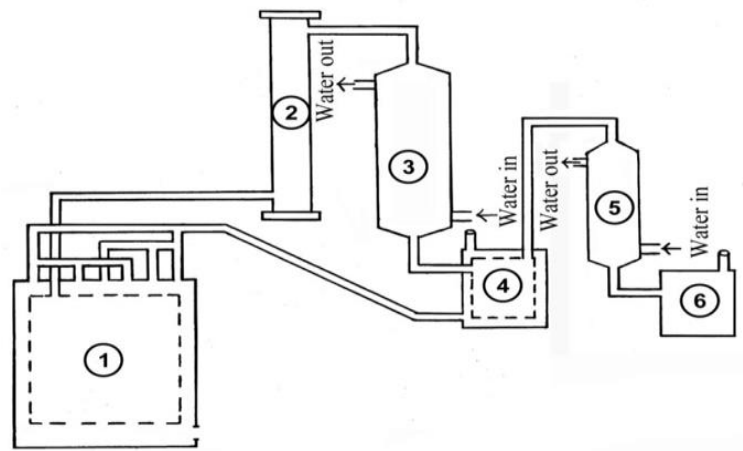

Fig. 1. Pyrolysis plant (for $200 \mathrm{~kg}$ scrap tire). 


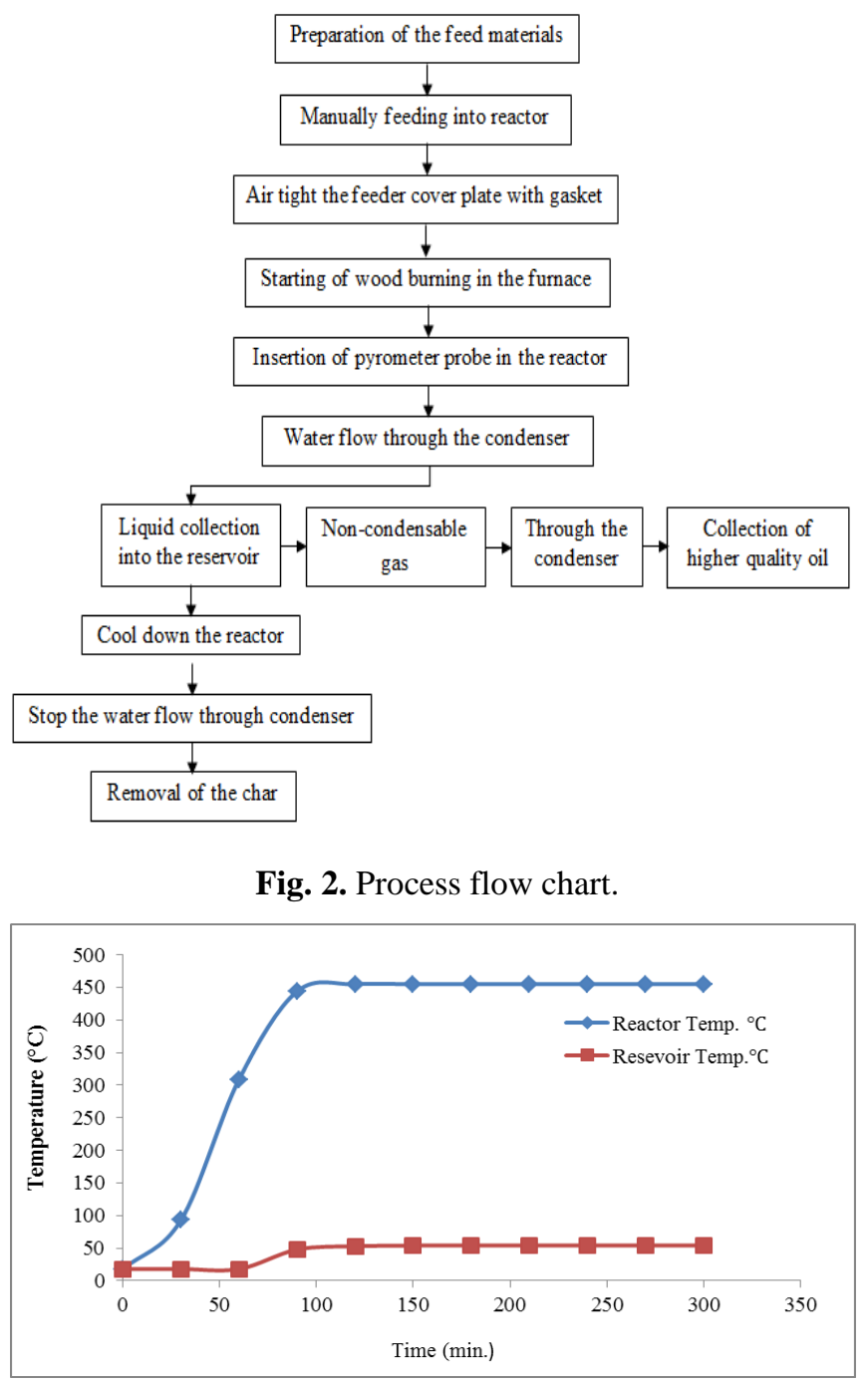

Fig. 3. Temperature distribution in reactor and reservoir with time.

Table 1. Data collected from pyrolysis unit during operation

\begin{tabular}{|c|c|c|c|c|}
\hline $\begin{array}{c}\text { Reactor } \\
\text { tempt. } \\
\left({ }^{\mathbf{}} \mathbf{C}\right)\end{array}$ & $\begin{array}{c}\text { Reservoir } \\
\text { tempt. } \\
\left({ }^{\circ} \mathbf{C}\right)\end{array}$ & $\begin{array}{c}\text { Water } \\
\text { Inlet } \\
\text { tempts. } \\
\left({ }^{\circ} \mathbf{C}\right)\end{array}$ & $\begin{array}{c}\text { Water } \\
\text { outlet } \\
\text { tempts. } \\
\left({ }^{\circ} \mathbf{C}\right)\end{array}$ & $\begin{array}{c}\text { Condenser } \\
\text { water flow } \\
\text { rate } \\
(\text { Lit./min. })\end{array}$ \\
\hline 18 & 18 & 18 & 18 & 20 \\
\hline 93 & 18 & 18 & 18 & 20 \\
\hline 309 & 18 & 18 & 21 & 20 \\
\hline 444 & 48 & 19 & 22 & 20 \\
\hline 455 & 53 & 20 & 24 & 20 \\
\hline 455 & 54 & 20 & 25 & 20 \\
\hline 455 & 54 & 20 & 25 & 20 \\
\hline 455 & 54 & 20 & 25 & 20 \\
\hline 455 & 54 & 20 & 25 & 20 \\
\hline 455 & 54 & 20 & 25 & 20 \\
\hline 455 & 54 & 20 & 25 & 20 \\
\hline & & & & \\
\hline
\end{tabular}

The product distributions obtained from the pilot plant experiments are presented in Table 2. In Table 3 the properties of TPO is shown and comparison results is given in Table 4.

Table 2. Product yields distribution of tire pyrolysis for different sizes

\begin{tabular}{|c|c|c|c|c|c|}
\hline \multirow[b]{2}{*}{$\begin{array}{l}\text { Feed size } \\
\quad(\mathrm{cm})\end{array}$} & \multirow{2}{*}{$\begin{array}{l}\text { Tire } \\
\text { feed } \\
(\mathrm{Kg})\end{array}$} & \multicolumn{4}{|c|}{ Product yield } \\
\hline & & Liquid & Char & $\begin{array}{c}\text { Higher } \\
\text { quality } \\
\text { oil }\end{array}$ & Gas \\
\hline $15 \times 15 \times 3$ & 200 & $\begin{array}{l}66 \mathrm{~kg} \\
(33 \%)\end{array}$ & $\begin{array}{l}112 \mathrm{~kg} \\
(56 \%)\end{array}$ & $\begin{array}{l}1.1 \mathrm{~kg} \\
(0.55 \%)\end{array}$ & $10.45 \%$ \\
\hline $20 \times 20 \times 3$ & 200 & $\begin{array}{l}86 \mathrm{~kg} \\
(43 \%)\end{array}$ & $\begin{array}{l}94 \mathrm{~kg} \\
(47 \%)\end{array}$ & $\begin{array}{l}1.5 \mathrm{~kg} \\
(0.75 \%)\end{array}$ & $9.25 \%$ \\
\hline
\end{tabular}

Table 3. Properties of diesel, crude TPO, TPO

\begin{tabular}{|l|c|c|c|}
\hline \multicolumn{1}{|c|}{ Property } & $\begin{array}{c}\text { Conventional } \\
\text { diesel }\end{array}$ & $\begin{array}{c}\text { Crude } \\
\text { TPO }\end{array}$ & TPO \\
\hline Density $\left(\mathrm{kg} / \mathrm{m}^{3}\right)$ & 872.3 & 942.6 & 848.69 \\
\hline $\begin{array}{l}\text { Viscosity }(\mathrm{centi} \\
\text { poise })\left(\text { at } 30\left({ }^{\circ} \mathrm{C}\right)\right.\end{array}$ & 4 & 4.2 & 1.4 \\
\hline $\begin{array}{l}\text { Calorific value } \\
(\mathrm{MJ} / \mathrm{kg})\end{array}$ & 44.832 & 41.5 & 42.37 \\
\hline Flash point $\left({ }^{\circ} \mathrm{C}\right)$ & 65 & 40 & 45.7 \\
\hline Pour point $\left({ }^{\circ} \mathrm{C}\right)$ & -30 to -40 & -2 & -6 \\
\hline
\end{tabular}

Table 4. Comparing the properties of our TPO with a reference book [12]

\begin{tabular}{|l|c|c|c|}
\hline \multicolumn{1}{|c|}{ Property } & $\begin{array}{c}\text { Conventional } \\
\text { Diesel }\end{array}$ & $\begin{array}{c}\text { Crude } \\
\text { TPO }\end{array}$ & TPO \\
\hline Density $\left(\mathrm{kg} / \mathrm{m}^{3}\right)$ & 830 & 935 & 871 \\
\hline $\begin{array}{l}\text { Viscosity }(\mathrm{centi} \\
\text { poise }\left(\text { at } 40^{\circ} \mathrm{C}\right)\end{array}$ & 2 & 3.2 & 1.7 \\
\hline $\begin{array}{l}\text { Calorific value } \\
(\mathrm{MJ} / \mathrm{kg})\end{array}$ & 46.5 & 42.83 & 45.78 \\
\hline Flash point $\left({ }^{\circ} \mathrm{C}\right)$ & 50 & 43 & 36 \\
\hline
\end{tabular}

\section{Fractional distillation}

In common industrial jargon, distillation is used sometimes to mean fractional, and not merely simple distillation. Fractional distillation or fractionation however, is in fact a special type of distillation, and as a separation technique, is much more effective than simple distillation and more efficient. In effect, fractionation is equivalent to a series of distillations, where the separation is achieved by successive distillations or repeated vaporizationcondensation cycles. Each vaporization-condensation cycle makes for an equilibrium stage, commonly known as a theoretical stage. A number of such theoretical stages may be 
required for the efficient fractionation and separation of the vapor or liquid mixture. Fig. 4 shows a simple fractional distillation column and its major parts are a. Electric heater, b. Round cylindrical reactor, c. Column, d. Thermometer adaptor, e. Condenser, and f. Oil collector.

Electric Heater: Electric heater was made by 3000 watt nicrome wire.

Round Cylindrical Reactor: The distillation column uses $8500 \mathrm{ml}$ round cylindrical reactor. The height of the reactor is $34.29 \mathrm{~cm}$, inner diameter is $17.78 \mathrm{~cm}$.

Column: Height of hollow column is $83.82 \mathrm{~cm}$. A number of general rules of thumb are used as a general guide before carrying out the actual calculations, but these rules often have exceptions.

Such rules as related to column diameter include the following four rules given below [13].

a. The length to diameter ratio should be less than 30 , preferably below 20, and tower height is to be limited to 60 meters because of wind load and foundation concerns. If the tower is higher than $60 \mathrm{~m}$, then a design with smaller tray spacing should be considered [14].

b. The ratio of tower diameter to random packing size is greater than 10 .

c. The tower diameter should be maintained at 1.2 meters at the top for vapor disengagement.

d. The tower diameter should be maintained at 2 meters at the bottom for liquid level and re-boiler return. In normal practice, however, only one diameter is calculated for the whole column. Different column diameters would only be used where there is a considerable change in flow-rate. Changes in liquid rate can be allowed for by adjusting the liquid down comer areas [15]. If two or more diameters are calculated, say for the top and bottom sections of the column, then roughly speaking, when the difference in the calculated diameters exceeds $20 \%$, different diameters for the top and bottom sections are likely to be economical and sections having different diameters should be at least $600 \mathrm{~cm} \mathrm{(20} \mathrm{ft.)}$ in length. Otherwise the diameter should be uniform. The preliminary column diameter would then be the larger of the two calculated diameters [16].

Thermometer adopter: A small scale degree Celsius thermometer is used in this column. A thermometer holder holds this thermometer appropriate position which can give appropriate result. For proper holding the thermometer Mseal gum is used.

Condenser: For proper condensing purpose, a condenser is used as libig condenser where tap water is passing through it at moderate flow rate. During water flow tap water pipe is connected below the condenser and exhaust water pipe is above. The total length of condenser is 71.12 $\mathrm{cm}$, outer diameter is $7.62 \mathrm{~cm}$ and inner diameter is $2 \mathrm{~cm}$.

Oil collector: For different oil fraction collection, a special oil collector which can give out the non-condensable gases is used.

Insulation: Glass wool is an insulating material made from fibers of glass arranged using a binder into a texture similar to wool. The process traps many small pockets of air between the glass, and these small air pockets result in high thermal insulation properties. Glass wool is produced in rolls or in slabs, with different thermal and mechanical properties. It may also be produced as a material that can be sprayed or applied in place, on the surface to be insulated [17].

\subsection{Collection of crude TPO}

TPO is collected from the university inventory as in Fig. 5. The pyrolysis was done in a fixed bed pyrolysis reactor in a temperature range $350-400^{\circ} \mathrm{C}$. The setup includes a condenser and fractionating column. Nitrogen gas was used to maintain an inert environment. In this pyrolysis, an automobile tire was cut into a number of pieces and the bead, steel wires and fabrics were removed. Thick rubber portion at the periphery of the tire is made into small chips like piece.

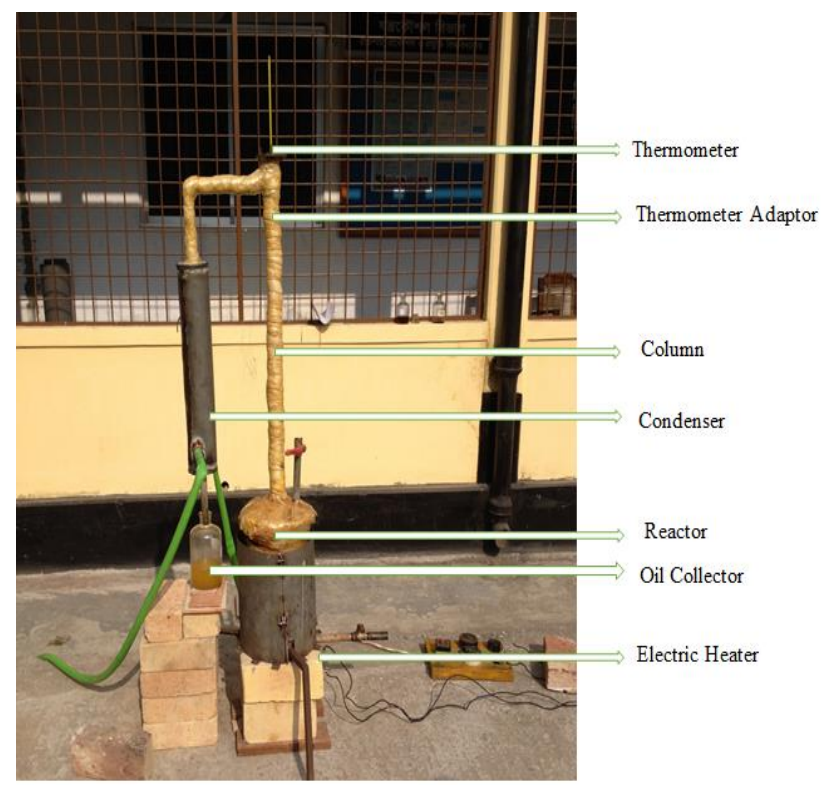

Fig. 4. Experimental set up for fractional distillation.

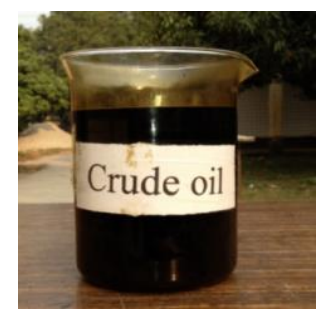

Fig. 5. Crude pyrolysis oil.

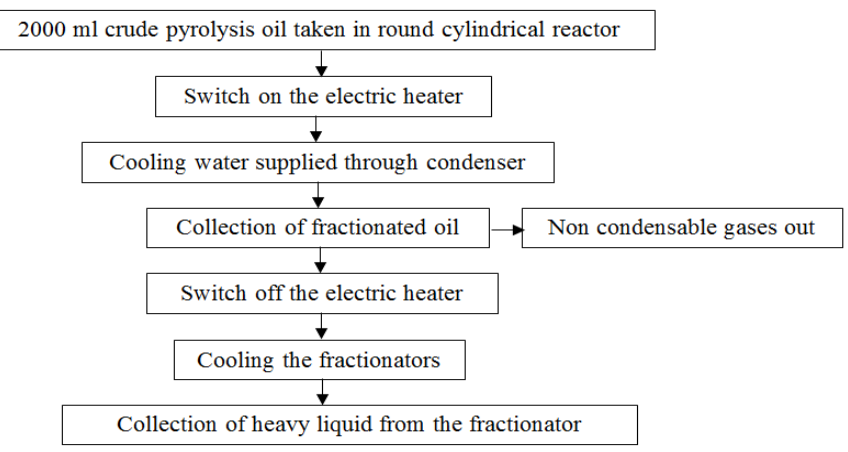

Fig. 6. Process flow chart of Fractional distillation. 


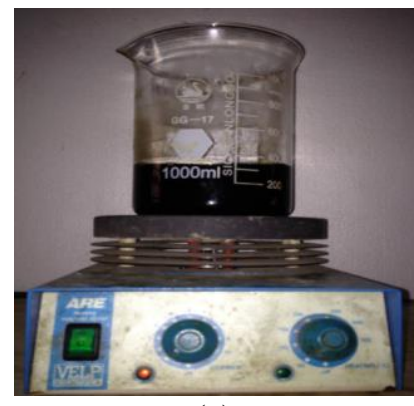

(a)

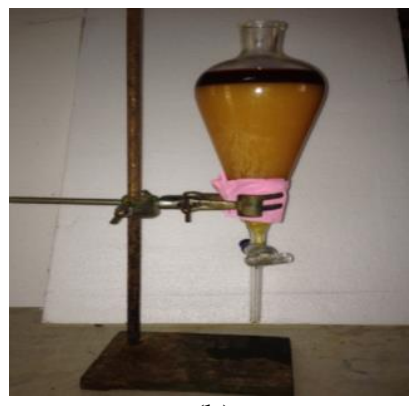

(b)

Fig. 7. (a) Desulfurization of oil; (b) Separation of oil.

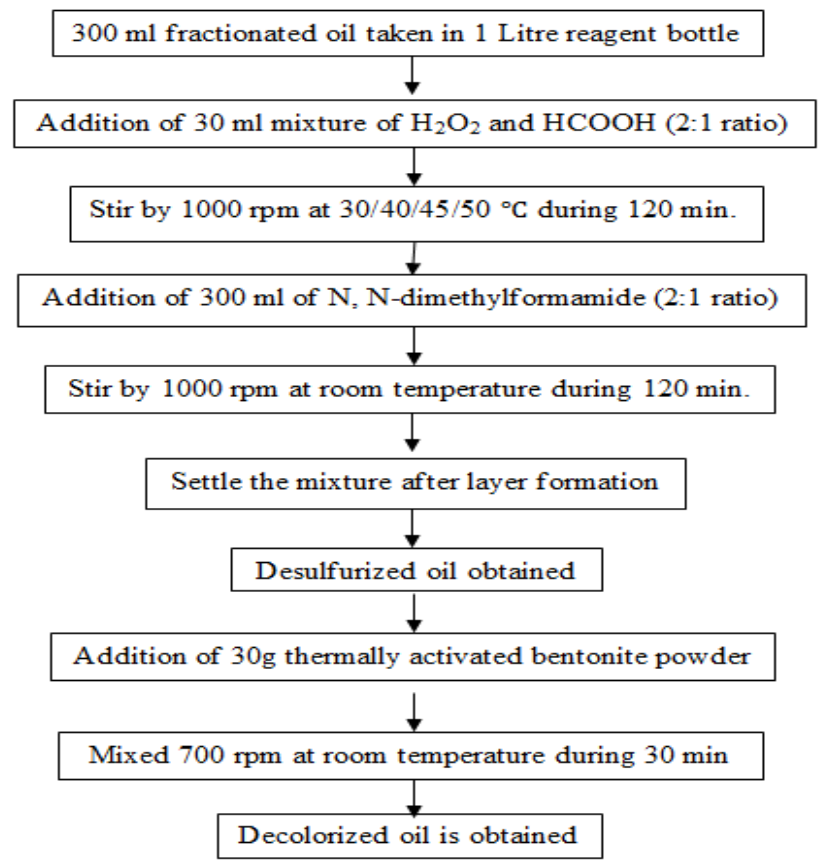

Fig. 8. Desulfurization and De-colorization of Fractionated oil.

The tire chips are washed and dried before feeding in the reactor unit. The chips feed is heated externally in absence of oxygen in the reactor. During the pyrolysis, large molecules of liquefied tires were converted into steam and rose out of the rector at high temperature. Vapor of these products is liquefied with the help of reactor condenser to obtain liquid product.

\subsection{Desulfurization of Fractionated oil}

The desulfurization as presented in Fig. 7 of fractionated oil has the following stages as mentioned in Fig. 8 .

Oxidation stage: In this step $10 \%$ solution of a mixture hydrogen peroxide and formic acid (2:1) is used. This mixture has mild oxidizing effect and oxidized the sulfur, which existing in the form of complex aromatic compound. In this step major of sulfur compound is oxidized. Another de-oxidation method may also be used but they have negative effect on the hydrocarbon mixture of pyrolysis oil.

Extraction stage: Extraction step is another most important step because in this step the oxygenated sulfur compound is extracted by suitable solvent.

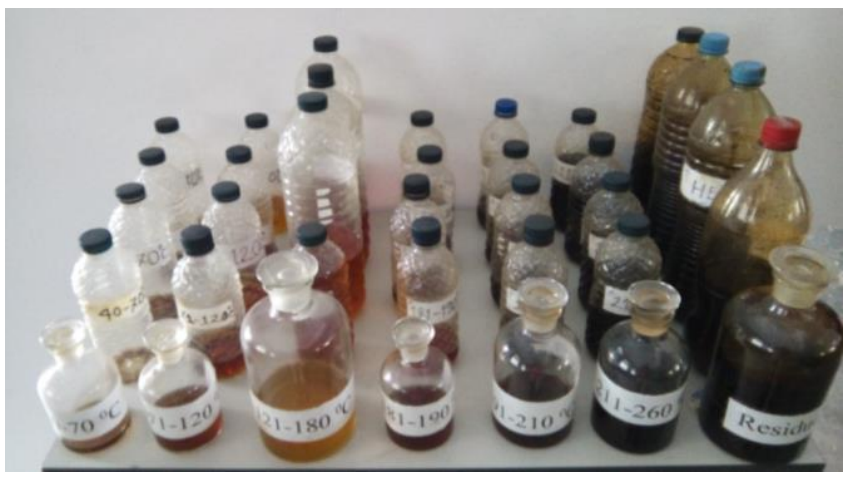

Fig. 9. Total upgraded oil yields from tire pyrolysis oil (TPO).

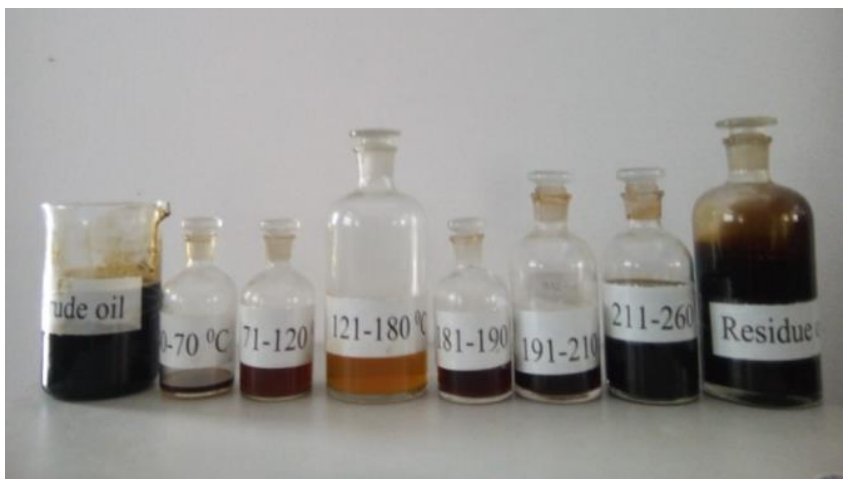

Fig. 10. Upgraded oil from tire pyrolysis oil (TPO).

The solvent may be ethanol, methanol, acetone, $\mathrm{N}, \mathrm{N}$ dimethyl formamide. But among this $\mathrm{N}$, N-dimethyl formamide is most effective for extraction of oxygenated compound.

\subsection{De-colorization of Fractionated oil}

For further de-colorization thermally activated bentonite powder is used by suitable $10 \mathrm{~g}$ weighed per $100 \mathrm{ml}$ oil sample. Magnetic stirrer is used for mixing the oil with bentonite powder. After filtration the filtrate oil color is developed.

\section{Results and Discussions}

\subsection{Upgrading by fractional distillation}

During upgrading process pyrolytic liquid is fractionated into seven parts by using distillation column as depicted in Fig. 9. Here pyrolytic liquid was classified as $40-70^{\circ} \mathrm{C}, 71-$ $120^{\circ} \mathrm{C}, 121-180^{\circ} \mathrm{C}, 181-190^{\circ} \mathrm{C}, 191-210^{\circ} \mathrm{C}, 210-260^{\circ} \mathrm{C}$, and non-fractionated residue oil by using their boiling point difference. Several successful runs were carried out by using prepared raw pyrolysis liquid samples to obtain sufficient amount of fractionated oil. The product distributions obtained from the fractional distillation process are presented in Table 5 and Fig. 10.

\subsection{Characterization of upgraded pyrolysis oil}

Pyrolytic liquids obtained under the maximum liquid yield conditions are well mixed and homogenized prior to 
analysis being made. Some physical properties of pyrolytic liquids are density, viscosity, flash point, pour point and GCV is determined by using proximate analysis that satisfies following ASTM D189, ASTM D445, ASTM D92, ASTM D97 and ASTM D240 international standards. Proximate analysis of a fuel provides a simple breakdown of the components volatile matter, moisture and ash, thereby giving an indication of the combustion characteristics of the fuel. The proximate analysis of crude, upgrade tire pyrolysis oil and conventional diesel fuel are shown in Table 6. This table also presents the fuel properties of the pyrolytic liquids in comparison to commercial automotive diesel, which is mostly consumed in Bangladesh. Elemental analysis of liquids is determined with an elemental analyzer of model
EA 15137078, which followed the quantitative "dynamic flash combustion" method.

Thus, the functional group compositions of the product liquids are analyzed by Fourier Transform Infra-Red FT-IR (Fourier Transform Infrared Spectrometer) spectroscopy. FTIR spectrometers are widely used in organic synthesis, polymer science, petrochemical engineering, pharmaceutical industry and food analysis. In addition, since FT-IR spectrometers can be hyphenated to chromatography, the mechanism of chemical reactions and the detection of unstable substances can be investigated with such instruments [18]. FT-IR spectra analysis results for upgraded pyrolysis oil over temperature range of $40-260{ }^{\circ} \mathrm{C}$ are given in Table 7 to Table 12.

Table 5. Oil obtained at different temperature range by fractional distillation for $2000 \mathrm{ml}$ crude pyrolytic oil

\begin{tabular}{|l|c|c|c|c|c|c|c|c|}
\hline \multicolumn{1}{|c|}{ Temp. Range $\left({ }^{\circ} \mathbf{C}\right)$} & $\mathbf{4 0 - 7 0}$ & $\mathbf{7 1 - 1 2 0}$ & $\mathbf{1 2 1 - 1 8 0}$ & $\mathbf{1 8 1 - 1 9 0}$ & $\mathbf{1 9 1 - 2 1 0}$ & $\mathbf{2 1 1 - 2 6 0}$ & Residue oil & Distillation loss \\
\hline Oil obtained in volume (ml) & 23.4 & 110 & 578 & 100 & 130.6 & 395 & 643 & 26 \\
\hline Oil obtained in $(\%)$ & 1.17 & 5.5 & 28.9 & 5 & 6.53 & 19.5 & 32.15 & 1.5 \\
\hline
\end{tabular}

Table 6. Comparison the properties of crude tire pyrolytic oil, fractionated oil with conventional diesel fuel

\begin{tabular}{|l|c|c|c|c|c|c|c|c|}
\hline \multicolumn{1}{|c|}{ Properties } & \multirow{2}{*}{$\begin{array}{c}\text { Crude } \\
\text { tire oil }\end{array}$} & \multicolumn{6}{c|}{ Upgrading fractionated oil ${ }^{\circ}$ C } & $\begin{array}{c}\text { Conventional } \\
\text { Diesel Fuel }\end{array}$ \\
\cline { 3 - 9 } & & $\mathbf{4 0 - 7 0}$ & $\mathbf{7 1 - 1 2 0}$ & $\begin{array}{c}\mathbf{1 2 1 -} \\
\mathbf{1 8 0}\end{array}$ & $\mathbf{1 8 1 - 1 9 0}$ & $\mathbf{1 9 1 - 2 1 0}$ & $\mathbf{2 1 1 - 2 6 0}$ & 831 \\
\hline $\begin{array}{l}\text { Density }\left(\mathrm{kg} / \mathrm{m}^{3}\right) \text { at } \\
20^{\circ} \mathrm{C}\end{array}$ & 942.6 & 791.5 & 802.98 & 848.69 & 876.276 & 892.863 & 931.94 & \\
\hline $\begin{array}{l}\text { Viscosity }\left(\text { at } 20^{\circ} \mathrm{C},\right. \\
\text { Centri poise })\end{array}$ & 3.5 & - & - & 1.4 & - & - & 3.5 & 4 \\
\hline Flash point $\left({ }^{\circ} \mathrm{C}\right)$ & 69 & 42.3 & 45.7 & 53.4 & 69.2 & 71.5 & 78.5 & 65 \\
\hline Fire point $\left({ }^{\circ} \mathrm{C}\right)$ & 95 & 72.1 & 81 & 130.5 & 155.2 & 167.5 & 174.2 & 228 \\
\hline Pour point $\left({ }^{\circ} \mathrm{C}\right)$ & $<-23$ & $<-23$ & $<-23$ & $<-23$ & $<-23$ & $<-23$ & $<-23$ & $-30-40$ \\
\hline Calorific value & 41.5 & 42.3 & 42.37 & 42.37 & 42.37 & 42.37 & 42.37 & 44.832 \\
\hline Color & $\begin{array}{c}\text { Brownish } \\
\text { black }\end{array}$ & $\begin{array}{c}\text { Black } \\
\text { tea } \\
\text { liquor }\end{array}$ & $\begin{array}{c}\text { Blackish } \\
\text { red }\end{array}$ & orange & $\begin{array}{c}\text { Black tea } \\
\text { liquor }\end{array}$ & $\begin{array}{c}\text { Blackish } \\
\text { red }\end{array}$ & $\begin{array}{c}\text { Brownish } \\
\text { black }\end{array}$ & Green tea liquor \\
\end{tabular}

Table 7. FT-IR spectra for upgraded pyrolysis oil over temperature range of $40-70{ }^{0} \mathrm{C}$

\begin{tabular}{|c|c|c|c|}
\hline Functional group & Theoretical frequency range $\left(\mathrm{cm}^{-1}\right)$ & Actual peak & Class of compounds \\
\hline C-H stretching & near 3000 & - & \multirow[t]{2}{*}{ Alkanes } \\
\hline $\mathrm{CH}_{2}$ and $\mathrm{CH}_{3}$ bending & $1475-1365$ & 1456.26 and 1375.25 & \\
\hline C-H bending (oop) & $1000-650$ & $891.11,825.53,723.31,677.01$ & Alkenes \\
\hline $\mathrm{C}=\mathrm{C}$ stretching & $1600-1450$ & 1456.26 & \multirow[t]{2}{*}{ Aromatic rings } \\
\hline $\mathrm{C}=\mathrm{C}($ oop $)$ & $900-690$ & $891.11,825.53,723.31,677.01$ & \\
\hline $\mathrm{C}=\mathrm{O}$ stretch & $1850-1650$ & 1670.35 & Carbonyl group \\
\hline $\mathrm{C}-\mathrm{H}$ & $2850-2750$ & - & Aldehydes (doublet) \\
\hline $\mathrm{C}=\mathrm{O}$ & $1680-1630$ & - & Amides \\
\hline $\mathrm{C}-\mathrm{Cl}$ & $730-550$ & \multirow[t]{2}{*}{-} & Acid chlorides \\
\hline $\mathrm{N}=\mathrm{O}$ asymmetric stretch & $1600-1530$ & & Nitro group(aliphatic) \\
\hline $\mathrm{S}=\mathrm{O}$ asymmetric stretch & 1375 & 1375.25 & Sulfonyl chlorides \\
\hline $\mathrm{N}-\mathrm{H}$ bend & 1550 & - & Sulfonamides \\
\hline
\end{tabular}


INTERNATIONAL JOURNAL Of ENGINEERING TECHNOLOGIES-IJET

Makhan Mia et al., Vol.3, No.1, 2017

Table 8. FT-IR spectra for upgraded pyrolysis oil over temperature range of $71-120{ }^{\circ} \mathrm{C}$

\begin{tabular}{|c|c|c|c|}
\hline Functional group & Theoretical frequency range $\left(\mathrm{cm}^{-1}\right)$ & Actual peak & Class of compounds \\
\hline C-H stretching & near 3000 & 2958.80 & \multirow[t]{2}{*}{ Alkanes } \\
\hline $\mathrm{CH}_{2}$ and $\mathrm{CH}_{3}$ bending & $1475-1365$ & 1456.26 and 1377.17 & \\
\hline C-H stretching & greater 3000 & - & \multirow[t]{2}{*}{ Alkenes } \\
\hline C-H bending (oop) & $1000-650$ & $817.82,813.36,677.01$ & \\
\hline $\mathrm{C}=\mathrm{C}$ stretching & $1600-1450$ & 1494.83 & \multirow[t]{2}{*}{ Aromatic rings } \\
\hline $\mathrm{C}=\mathrm{C}(\mathrm{oop})$ & $900-690$ & $817.82,813.36,677.01$ & \\
\hline $\mathrm{C}=\mathrm{O}$ stretch & $1850-1650$ & & Carbonyl group \\
\hline $\mathrm{C}-\mathrm{H}$ & $2850-2750$ & - & $\begin{array}{l}\text { Aldehydes } \\
\text { (doublet) }\end{array}$ \\
\hline $\mathrm{C}-\mathrm{Cl}$ & $730-550$ & - & Acid chlorides \\
\hline $\mathrm{N}-\mathrm{H}$ bend & $1640-1560$ & 1558.48 & Secondary amines \\
\hline N-H (oop) & near 800 & - & Amines \\
\hline $\mathrm{N}=\mathrm{O}$ asymmetric stretch & $1550-1490$ & 1494.83 & $\begin{array}{c}\text { Nitro group } \\
\text { (aromatic) }\end{array}$ \\
\hline $\mathrm{S}=\mathrm{O}$ asymmetric stretch & 1375 & 1377.17 & Sulfonyl chlorides \\
\hline
\end{tabular}

Table 9. FT-IR spectra for upgraded pyrolysis oil over temperature range $121-180{ }^{\circ} \mathrm{C}$

\begin{tabular}{|c|c|c|c|}
\hline Functional group & Theoretical frequency range $\left(\mathrm{cm}^{-1}\right)$ & Actual peak & Class of compounds \\
\hline C-H stretching & near 3000 & 2973 & \multirow[t]{2}{*}{ Alkanes } \\
\hline $\mathrm{CH}_{2}$ and $\mathrm{CH}_{3}$ bending & $1475-1365$ & 1456.26 and 1377.17 & \\
\hline C-H stretching & greater 3000 & 3026.31 & Alkenes \\
\hline C-H bending (oop) & $1000-650$ & $889.18,694.37$ & - \\
\hline $\mathrm{C}=\mathrm{C}$ stretching & $1600-1450$ & 1456.26 & \multirow[t]{2}{*}{ Aromatic rings } \\
\hline $\mathrm{C}=\mathrm{C}(\mathrm{oop})$ & $900-690$ & $889.18,694.37$ & \\
\hline $\mathrm{C}=\mathrm{O}$ stretch & $1850-1650$ & - & Carbonyl group \\
\hline $\mathrm{C}-\mathrm{H}$ & $2850-2750$ & - & Aldehydes (doublet) \\
\hline $\mathrm{C}=\mathrm{O}$ & $1680-1630$ & - & Amides \\
\hline $\mathrm{C}-\mathrm{Cl}$ & $730-550$ & - & Acid chlorides \\
\hline $\mathrm{N}-\mathrm{H}$ bend & $1640-1560$ & - & Secondary amines \\
\hline N-H (oop) & near 800 & - & Amines \\
\hline $\mathrm{N}=\mathrm{O}$ asymmetric stretch & $1600-1530$ & - & Nitro group (aliphatic) \\
\hline $\mathrm{N}=\mathrm{O}$ asymmetric stretch & $1550-1490$ & - & Nitro group (aromatic) \\
\hline $\mathrm{S}=\mathrm{O}$ asymmetric stretch & 1375 & 1377.17 & Sulfonyl chlorides \\
\hline $\mathrm{N}-\mathrm{H}$ bend & 1550 & - & Sulfonamides \\
\hline $\mathrm{S}=\mathrm{O}$ asymmetric & 1350 & - & Sulfonic acids \\
\hline
\end{tabular}


INTERNATIONAL JOURNAL Of ENGINEERING TECHNOLOGIES-IJET

Makhan Mia et al., Vol.3, No.1, 2017

Table 10. FT-IR spectra for upgraded pyrolysis oil over temperature range $181-190{ }^{\circ} \mathrm{C}$

\begin{tabular}{|c|c|c|c|}
\hline Functional group & Theoretical frequency range $\left(\mathrm{cm}^{-1}\right)$ & Actual peak & Class of compounds \\
\hline C-H stretching & near 3000 & 2960.73 & \multirow[t]{2}{*}{ Alkanes } \\
\hline $\mathrm{CH}_{2}$ and $\mathrm{CH}_{3}$ bending & $1475-1365$ & 1456.26 and 1375.25 & \\
\hline C-H stretching & greater 3000 & 3016.67 & \multirow[t]{2}{*}{ Alkenes } \\
\hline C-H bending (oop) & $1000-650$ & $891.11,823.60,725.23$ & \\
\hline $\mathrm{C}=\mathrm{C}$ stretching & $1600-1450$ & 1506.41 & \multirow[t]{2}{*}{ Aromatic ring } \\
\hline $\mathrm{C}=\mathrm{C}($ oop $)$ & $900-690$ & $891.11,823.60,725.23$ & \\
\hline $\mathrm{C}=\mathrm{O}$ stretch & $1850-1650$ & 1683.86 & Carbonyl group \\
\hline $\mathrm{C}-\mathrm{H}$ & $2850-2750$ & - & Aldehydes (doublet) \\
\hline N-H stretch & $3475-3150$ & - & \multirow[t]{2}{*}{ Amides } \\
\hline $\mathrm{C}=\mathrm{O}$ & $1680-1630$ & - & \\
\hline $\mathrm{C}-\mathrm{Cl}$ & $730-550$ & 725.23 & Acid chlorides \\
\hline $\mathrm{N}-\mathrm{H}$ bend & $1640-1560$ & 1616.36 & Secondary amines \\
\hline N-H (oop) & near 800 & - & Amines \\
\hline $\mathrm{N}=\mathrm{O}$ asymmetric stretch & $1600-1530$ & - & \multirow[t]{2}{*}{ Nitro group(aliphatic) } \\
\hline $\mathrm{N}=\mathrm{O}$ asymmetric stretch & $1550-1490$ & & \\
\hline $\mathrm{S}=\mathrm{O}$ asymmetric stretch & 1375 & 1375.25 & Sulfonyl chlorides \\
\hline $\mathrm{N}-\mathrm{H}$ bend & 1550 & 1506.41 & Sulfonamides \\
\hline
\end{tabular}

Table 11. FT-IR spectra for upgraded pyrolysis oil over temperature range $191-210{ }^{\circ} \mathrm{C}$

\begin{tabular}{|c|c|c|c|}
\hline Functional Group & Theoretical frequency range $\left(\mathrm{cm}^{-1}\right)$ & Actual peak & Class of compounds \\
\hline C-H stretching & near 3000 & 2973 & \multirow[t]{2}{*}{ Alkanes } \\
\hline $\mathrm{CH}_{2}$ and $\mathrm{CH}_{3}$ bending & $1475-1365$ & 1456.25 and 1377.17 & \\
\hline C-H stretching & greater 3000 & 3016.67 & Alkenes \\
\hline $\mathrm{C}-\mathrm{H}$ bending (oop) & $1000-650$ & $891.11,821.68,740.67,690.52$ & \multirow[t]{2}{*}{ Aromatic rings } \\
\hline $\mathrm{C}=\mathrm{C}$ stretching & $1600-1450$ & $1506.41,1456.26$ & \\
\hline $\mathrm{C}=\mathrm{C}$ bending $(\mathrm{oop})$ & $900-690$ & $891.11,690.52$ & \multirow[t]{2}{*}{ Carbonyl group } \\
\hline $\mathrm{C}=\mathrm{O}$ stretch & $1850-1650$ & 1670.35 & \\
\hline $\mathrm{C}-\mathrm{H}$ & $2850-2750$ & - & Aldehydes (doublet) \\
\hline $\mathrm{C}=\mathrm{O}$ & $1680-1630$ & - & Amides \\
\hline N-H stretch & $3475-3150$ & - & \multirow[t]{2}{*}{ Acid chlorides } \\
\hline C-Cl stretch & $730-550$ & - & \\
\hline $\mathrm{N}-\mathrm{H}$ bend & $1640-1560$ & - & Secondary amines \\
\hline N-H (oop) & near 800 & - & Amines \\
\hline $\mathrm{N}=\mathrm{O}$ asymmetric stretch & $1600-1530$ & 1558.48 & $\begin{array}{c}\text { Nitro group } \\
\text { (aliphatic) }\end{array}$ \\
\hline $\mathrm{N}=\mathrm{O}$ asymmetric stretch & $1550-1490$ & 1506.41 & $\begin{array}{l}\text { Nitro group } \\
\text { (aromatic) }\end{array}$ \\
\hline $\mathrm{S}=\mathrm{O}$ asymmetric stretch & 1375 & 1377.17 & Sulfonyl chlorides \\
\hline $\mathrm{N}-\mathrm{H}$ bend & 1550 & - & Sulfonamides \\
\hline
\end{tabular}


Table 12. FT-IR spectra for upgraded pyrolysis oil over temperature range $211-260{ }^{\circ} \mathrm{C}$

\begin{tabular}{|c|c|c|c|}
\hline Functional group & Theoretical frequency range $\left(\mathrm{cm}^{-1}\right)$ & Actual peak & Class of compounds \\
\hline $\mathrm{C}-\mathrm{H}$ stretching & near 3000 & 2956.87 & \multirow[t]{2}{*}{ Alkanes } \\
\hline $\mathrm{CH}_{2}$ and $\mathrm{CH}_{3}$ bending & $1475-1365$ & 1456.26 and 1375.25 & \\
\hline C-H stretching & greater 3000 & 3400 & \multirow[t]{2}{*}{ Alkenes } \\
\hline C-H bending (oop) & $1000-650$ & - & \\
\hline $\mathrm{C}=\mathrm{C}$ stretching & $1600-1450$ & $1558.48,1506.41,1456.2$ & \multirow[t]{2}{*}{ Aromatic rings } \\
\hline $\mathrm{C}=\mathrm{C}(\mathrm{oop})$ & $900-690$ & 730 & \\
\hline $\mathrm{C}-\mathrm{O}$ stretch & $1260-1000$ & $1197.79,1122.57$ & Phenols \\
\hline $\mathrm{C}=\mathrm{O}$ stretch & $1850-1650$ & 1670.35 & Carbonyl group \\
\hline $\mathrm{C}-\mathrm{H}$ & $2850-2750$ & - & Aldehydes (doublet) \\
\hline $\mathrm{C}=\mathrm{O}$ & $1680-1630$ & 1670.35 & Amides \\
\hline $\mathrm{C}-\mathrm{Cl}$ & $730-550$ & - & Acid chlorides \\
\hline $\mathrm{C}-\mathrm{O}$ stretch & $1300-900$ & $11197.79,1122.57$ & Anhydrides \\
\hline N-H stretch & $3500-3300$ & - & Amines \\
\hline $\mathrm{N}-\mathrm{H}$ bend & $1640-1560$ & 1558.48 & Secondary amines \\
\hline N-H (oop) & near 800 & - & Amines \\
\hline $\mathrm{N}=\mathrm{O}$ asymmetric stretch & $1600-1530$ & 1558.48 & \multirow[t]{2}{*}{ Nitro group(aliphatic) } \\
\hline $\mathrm{N}=\mathrm{O}$ asymmetric stretch & $1550-1490$ & 1506.41 & \\
\hline $\mathrm{S}=\mathrm{O}$ asymmetric stretch & 1375 & 1375.25 & Sulfonyl chlorides \\
\hline N-H bend & 1550 & - & Sulfonamides \\
\hline
\end{tabular}

\section{Conclusions and Recommendations}

The physical and chemical characterizations of the raw pyrolysis oil derived from light automotive tire waste has been carried out and compared with conventional fuels. The pyrolytic liquids obtained from pyrolysis of automotive tire wastes, which are oily organic compounds, appears dark-brown-color with a strong acrid smell. Careful handling of the liquids is required since it reacts easily with human skins, leaving permanent yellowish brown marks and an acrid smell for a few days, which is difficult to remove by detergent. No phase separation was found to take place in the storage bottles. Experimental consequences are summarized below-

a. Improved pyrolysis system is designed, so that higher quality oil possible to separate from crude tire pyrolysis oil reservoir.

b. Fractional distillation yields more pyro-oil in the temperature range of $121-180^{\circ} \mathrm{C}$.

c. The density of fractionated pyrolytic liquids is found lower than that of the commercial diesel fuel and also lower than that of heavy fuel oil.

d. The density of $40-70^{\circ} \mathrm{C}, 71-120^{\circ} \mathrm{C}, 121-180^{\circ} \mathrm{C}, 181-$ $190^{\circ} \mathrm{C}, 191-210^{\circ} \mathrm{C}, 211-260^{\circ} \mathrm{C}$ are $791.5,802.98$, $848.69,876.276,892.863,931.94\left(\mathrm{~kg} / \mathrm{m}^{3}\right)$ at $20^{\circ} \mathrm{C}$.
Where conventional diesel fuel has density $831\left(\mathrm{~kg} / \mathrm{m}^{3}\right)$.

e. The viscosity of fractionated liquid products from tire wastes is slightly lower than that of the diesel but also much lower than that of heavy fuel oil. Low viscosity of the liquids at $121-180^{\circ} \mathrm{C}$ and $211-260^{\circ} \mathrm{C}$ are 1.4 and $3.5 \mathrm{Centri}$ poise at $20^{\circ} \mathrm{C}$ and conventional diesel fuel has viscosity 4.0 Centri poise at $27^{\circ} \mathrm{C}$ is a favorable feature in the handling and transporting of the liquid.

f. The flash point of the tire-derived crude liquid at 40$70^{\circ} \mathrm{C}, \quad 71-120^{\circ} \mathrm{C}, \quad 121-180^{\circ} \mathrm{C}, \quad 181-190^{\circ} \mathrm{C}, \quad 191-$ $210^{\circ} \mathrm{C}, 211-260^{\circ} \mathrm{C}$ oils are $42.3^{\circ} \mathrm{C}, 45.7^{\circ} \mathrm{C}, 53.4^{\circ} \mathrm{C}$, $69.2^{\circ} \mathrm{C}, 71.5^{\circ} \mathrm{C} 78.5^{\circ} \mathrm{C}$ obtained at $20^{\circ} \mathrm{C}$ and for conventional diesel fuel $65^{\circ} \mathrm{C}$ obtained at $27^{\circ} \mathrm{C}$. The flash point is low when compared with petroleumrefined fuels.

g. The fire point at $40-70^{\circ} \mathrm{C}, 71-120^{\circ} \mathrm{C}, 121-180^{\circ} \mathrm{C}$, $181-190^{\circ} \mathrm{C} 191-210^{\circ} \mathrm{C}$ and $211-260^{\circ} \mathrm{C}$ oils are $72.1^{\circ} \mathrm{C}, 81^{\circ} \mathrm{C}, 130.5^{\circ} \mathrm{C}, 155.2^{\circ} \mathrm{C}, 167.5^{\circ} \mathrm{C}, 174.2^{\circ} \mathrm{C}$ and conventional diesel fuel is $228^{\circ} \mathrm{C}$, which is greater than fractionated oil.

h. The pour point of the tire-derived liquids is $-6{ }^{\circ} \mathrm{C}$. The calorific value of the upgraded tire oil is 42.37 $\mathrm{MJ} / \mathrm{Kg}$. The calorific value is high and comparable 
with that of a diesel fuel oil, indicating the potential for the use of tire derived oils as fuel.

i. The upgraded fractionated oil has lower viscosity, good spray quality and proper combustion with compared to conventional fuel.

j. The pyrolytic liquids abundantly contain olefins, specially limonene and light aromatics, whose have higher market values as chemical feedstock than their use as fuels.

Some steps may be taken to improve the oil grade. The foregoing recommendations are-

a. Special glass made fractional column is recommended for smooth or perfect operation as metal has conductivity higher than glass.

b. The TPO has many impurities and odor, which causes its use difficult. Further chemical and physical treatment is required to remove this.

c. The color of TPO is not stable, it changes with time as there some sludge remains. To prevent this problem some further steps should be taken.

d. The unit production cost of pyrolysis oil and upgrading by suitable method is analyzed suitably for large scale production.

e. Finally, it may be concluded that the fractional distillation can be run only under continuous monitoring and consultancy support of a tire pyrolysis specialist team.

\section{Acknowledgement}

The authors acknowledge the gratitude to Rajshahi University of Engineering \& Technology, Bangladesh for the benevolent attitude such as mental support, guidance and allowing using research labs.

\section{References}

[1] Scrap tire markets in the United States, 9th Biennial Report, Rubber Manufacturers Association, May 2009.

[2] Rubber Manufacturers Association (RMA), Scrap Tire Markets in the United States; 2005.

[3] A. M. Mastral, R. Murillo , M. S. Callen, and T. Garcia, "Optimisation of scrap automotive tyres recycling into valuable liquid fuels", Resources, Conservation and Recycling, Vol. 29, Issue 4, pp. 263-272, June 2000.

[4] A. M. Cunliffe, and P. T. Williams, "Composition of oils derived from the batch pyrolysis of tyres", Journal of Analytical and Applied Pyrolysis, Vol. 44, Issue 2, pp. 131-152, January 1998.

[5] P. T. Williams, and A. J. Brindle, "Temperature selective condensation of tyre pyrolysisoils to maximise the recovery of single ring aromatic compounds", Fuel, Vol. 82, Issue 9, pp. 1023-1031, June 2003.
[6] S. Ucar, S. Karagoz, A. R. Ozkan, and J. Yanik, "Evaluation of two different scrap tires ash hydrocarbon source by pyrolysis", Fuel, Vol. 84, Issues 14-15, pp. 1884-1892, October 2005.

[7] C. Berrueco, E. Esperanza, F. J. Mastral, J. Ceamanos, and P. Garc1'a-Bacaicoa, "Pyrolysis of waste tyres in a atmospheric static-bed batch reactor", Journal of Analytical and Applied Pyrolysis, Vol. 74, Issues 1-2, pp. 245-253, August 2005.

[8] Isabel de Marco Rodriguez, M. F. Laresgoiti, M. A. Cabrero, A Torres, M. J. Chomón, and B. Caballero, "Pyrolysis of scrap tyres", Fuel Processing Technology, Vol. 72, Issue 1, pp. 9-22, August 2001.

[9] M. R. Islam, M. N. Islam, N. N. Mustafi, M. A. Rahim, and H. Haniu, "Thermal recycling of solid tire wastes for alternative liquid fuel: the first commercial step in Bangladesh", Procedia Engineering Vol. 56, pp. 573-582, 2013.

[10] S. Murugan, M. C. Ramaswamy, and G. Nagarajan, A comparative study on the performance, emission and combustion studies of a DI diesel engine using distilled tire pyrolysis oil-diesel blends, Fuel, Vol. 87, Issues 10-11, pp. 2111-2121, August 2008.

[11] S. Murugan, M. C. Ramaswamy, and G. Nagarajan, The use of tire pyrolysis oil in diesel engines, Waste Management, Vol. 28, Issue 12, pp. 2743-2749, December 2008.

[12] J. L. Humphrey, and G. E. Keller, Separation Process Technology, New York: McGraw-Hill, 1997, ch. 1.

[13] K. Kolmetz, W. K. Ng, S. H. Lee, T. Y. Lim, D. R. Summers, and C. A. Soyza, "Optimize distillation column design for improved reliability in operation and maintenance", 2nd Best Practices in Process Plant Management, Kuala Lumpur, Malaysia, March 14-15, 2005.

[14] Distillation Column Selection and Sizing. KLM Technology group, Available at: www.klmtechgroup.com, 2011.

[15] R. K. Sinnott, Coulson \& Richardson's Chemical Engineering, 4th ed., Vol. 6. Elsevier, 2006, pp. 564565 .

[16] H. Z. Kister, Distillation design. New York: McGraw-Hill Book Co., 1992, ch. 3.

[17] Uses and Benefits of Glass Wool, https://storify.com/VarunSharma123/uses-and benefitsof-glass-wool, 2016.

[18] How an FTIR Spectrometer Operates. Available at:http://chemwiki.ucdavis.edu/Core/Physical_Chemistr y/Spectroscopy/Vibrational_Spectroscopy/Infrared_Spe ctroscopy/How_an_FTIR_Spectrometer_Operates, 2016. 